\title{
Investigation of the Tank Model for Urban Storm Water \\ Management
}

\author{
Xinjie Ou, ${ }^{1}$ Bahram Gharabaghi, ${ }^{1}$ Ed McBean ${ }^{1}$ and Chris Doherty ${ }^{2}$ \\ ${ }^{1}$ University of Guelph, Guelph, Ontario; ${ }^{2} E W R G$, Mississauga, Ontario.
}

\begin{abstract}
The effect of impervious surfaces in urbanizing watersheds on stormwater runoff volumes and peak flood flows is investigated using a lumped hydrologic model, known as the Tank model, for the urbanized Mimico Creek watershed in Ontario. This model includes a separate algorithm for the simulation of stormwater runoff from impervious surfaces and an algorithm for the simulation of runoff and baseflow generated from pervious areas of the watershed. The simulated daily flow records of the calibrated model matched well with observed historic flow records. Since Mimico Creek is currently at 50\% imperviousness; the model to simulate the sensitivity to change in streamflow for both $40 \%$ and $60 \%$ imperviousness scenarios is demonstrated. This study presents a simple novel management tool for assessing the effect of change in imperviousness of an urban watershed on streamflow volumes and peak flood flows.
\end{abstract}

\section{Introduction}

Urbanization is an ongoing trend in virtually all nations. Highdensity urbanization results in significant increase in impermeable surface areas, with resultant flooding problems. However, new urban stormwater management systems have been introduced over the last few decades, known as low impact development (LID) systems. The primary focus of LID systems is to promote infiltration and to decrease the volume of surface runoff and peak flood flows by changing the effective imperviousness.

Various hydrologic models, including the BC Water Balance Model; PC-SWMM, EPA National Stormwater Calculator, WinSLAMM, MIDS GUI Credit Calculator, and GIS-Calculator have been used to investigate the application of LID systems (Yates 1996; Elliott and Trowsdale 2007; Dietz 2007; Dietz and Clausen 2008; Finney et al. 2010; Basri 2013; Saini \& Singh 2016). This study investigates the application of a Tank model to assess the effects of imperviousness on urban streamflows. Although the Tank model has been widely used in Asian countries, no evidence of its application in Canada was found.

\section{Study Area}

\subsection{General Information}

Mimico Creek begins in Brampton, then flows through part of Mississauga and past Toronto Pearson International Airport, and finally ends in Lake Ontario. The length of Mimico Creek is $33 \mathrm{~km}$, and the area of the basin is $77 \mathrm{~km}^{2}$ (Nirupama et al. 2014). The shaded area in Figure 1 shows the area of the Mimico Creek watershed. Mimico Creek watershed is one of the most highly developed watersheds in the Greater Toronto Area (TRCA 2012).

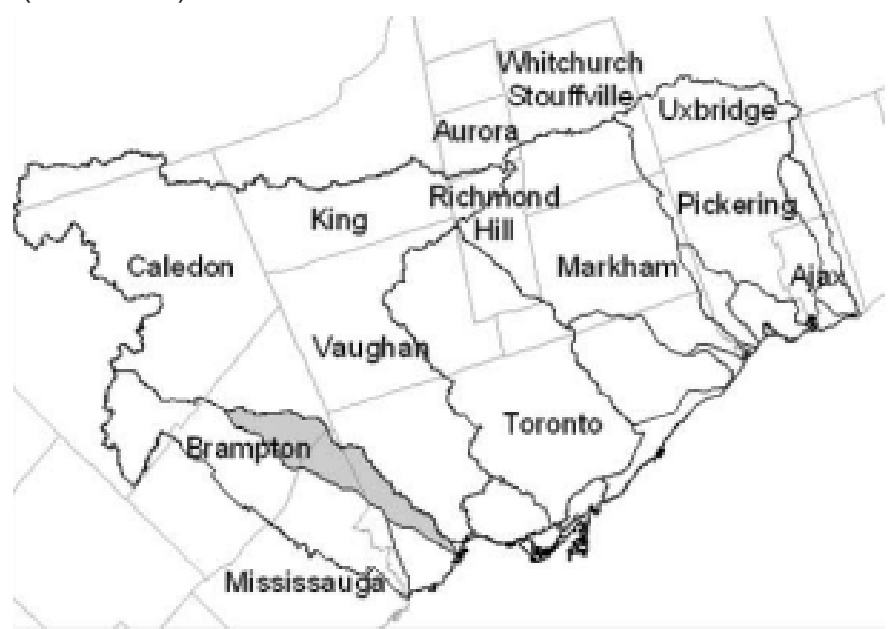

Figure 1 Mimico Creek watershed area (Source: TRCA 2012).

The hydrometric station of Mimico Creek is located in Islington, $5 \mathrm{~km}$ away from its mouth, namely $02 \mathrm{HC} 033$.

\subsection{Imperviousness Calculation}

UDFCD (2001) recommends percentage imperviousness values for different types of land use; the selected values are shown in Table 1.

Ou, Xinjie, Bahram Gharabaghi, Ed McBean and Chris Doherty. 2017. Investigation of the Tank Model for Urban Storm Water Management. Journal of Water Management Modeling 25:C421. https://doi.org/10.14796/JWMM.C421 C CHI 2017. www.chijournal.org ISSN 2292-6062. 
Table 1 Urban Drainage and Flood Control District recommended percentage imperviousness values (UDFCD, 2001).

\begin{tabular}{lcc}
\hline \multicolumn{1}{c}{ Land use type } & \% Watershed area & \% Impervious cover for this land use \\
\hline Commercial & 5.4 & $85 \%$ \\
Industrial & 20.4 & $85 \%$ \\
Institutional & 5.7 & $50 \%$ \\
Open & 18.3 & $0 \%$ \\
Roads & 11.9 & $100 \%$ \\
Residential & 38.3 & $36 \%$ \\
\hline
\end{tabular}

However, based on the breakdown of the land uses and the percentage imperviousness of each land use category, the overall imperviousness of the Mimico Creek watershed is about $50 \%$.

\subsection{Observed Streamflow Data}

The daily flow data in Mimico Creek hydrometric station at Islington $(02 \mathrm{HC} 033)$ are available from 1965 to 2016, and water level records from 2002 to 2016. In this paper, three years of continuous data were used to calibrate the Tank model, for the period 1990-1992. The observed streamflow data of 2001 were used for Tank model validation.

\subsection{Precipitation}

Precipitation is the only input data for the Tank model. For this research, the daily precipitation data were obtained from Environment Canada. The selected meteorological station is Toronto Lester B. Pearson International Airport, which is near the centre of the study area and $9.18 \mathrm{~km}$ away from the hydrometric station, see Figure 2.

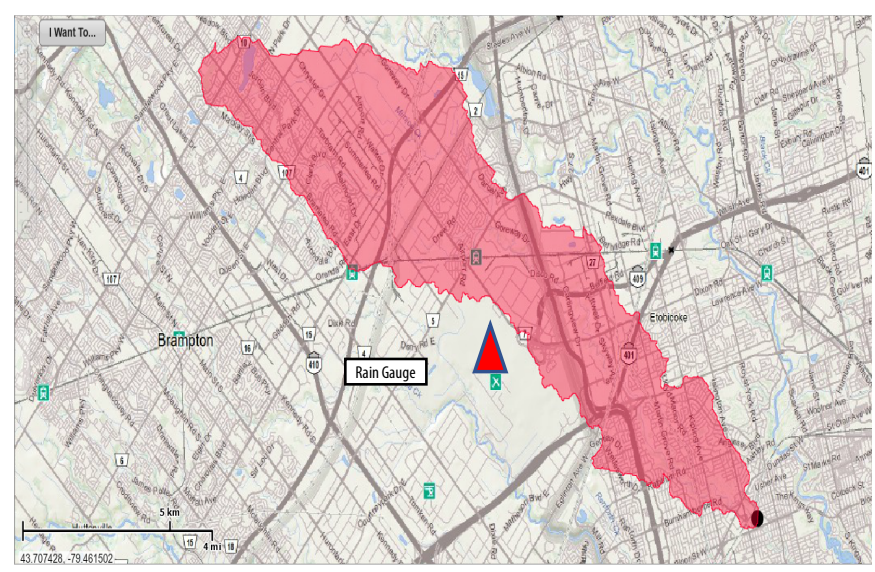

Figure 2 Drainage area for the Mimico Creek watershed.

The input to the Tank model is effective precipitation, not actual precipitation; however, the lack of evaporation data means that the effective precipitation cannot be calculated directly from the actual precipitation; hence the effective precipitation for the permeable Tank model were obtained using Equation 1, which is the actual precipitation multiplied by the weight of total observed discharge and total precipitation.

$$
E P_{i}=P_{i} \times \frac{\sum_{i=1}^{n} O b_{i}}{\sum_{i=1}^{n} P_{i}}
$$

where:

$$
E P_{i}=\text { effective precipitation }(\mathrm{mm}) \text { on the } i \text { th day, }
$$

$P_{i}=$ total precipitation $(\mathrm{mm})$ on the $i$ th day,

$O b_{i}=$ the ith day observed discharge $(\mathrm{mm})$, and

$n=$ total number of days.

Following the Urban Storm Drainage Criteria Manual (UDFCD 2001) recommendation, $2.54 \mathrm{~mm}$ is assumed as the depression loss for impervious land cover.

The average annual precipitation for the Mimico Creek watershed is $808 \mathrm{~mm}$. The daily precipitation data for this meteorological station are available from 1953 to 2013, and for this research, the period 1990-1992 was selected to calculate the Tank model input for calibration and sensitivity analysis. The observed precipitation of 2001 was used for the model validation.

\section{Tank Model}

\subsection{Structure}

The Tank model structure depends on the type of land use. A watershed does not consist of a single type of land use, but consists typically of two or more types. Basri (2013) summarizes how the Tank model structure varies with the land uses, such as urbanized area with only one tank, while garden areas and forest area are with three tanks and four tanks in vertical series, respectively.

To analyse how the imperviousness affects a city, a combination tank model was used for the Mimico Creek watershed. The study watershed was divided into permeable and impermeable areas. The impermeable tank model, which is to simulate the runoff from the $50 \%$ impermeable urban land use, is built like a settlement tank with only one tank having one side outlet. For the permeable tank model, the two layer tank model (Figure 3) was considered as an acceptable option to simulate the $50 \%$ permeable urban land use. For the impermeable tank model, effective precipitation as the single input of this type of model, was calculated by subtracting $0.1 \mathrm{in}$. $(2.54 \mathrm{~mm})$ from the daily precipitation. The output from the side outlet is surface runoff. For the permeable tank model, precipitation is the single input into the top tank, followed by subtraction of the evaporation from the same tank. Both of these two processes can be calculated using Equation 1, known as the effective precipitation.

There are two side outlets in the top tank, and one in the bottom tank for the permeable model. The outputs from the side outlets are termed runoffs. The output from the bottom outlet of the top tank is the infiltration, which would occur with the onset of precipitation. The principle of the two types of Tank model is to simulate the runoff base flow on the water balance. Chow et al. (1988) summarized the water balance equation for a watershed as shown in Equation 2. The water balance equations and its components of the Tank model for investigation are shown in 
Equations 2 through 10. Figure 3 presents the schematic diagram of the structure of the Tank model. These two Tank models were built independently, but their simulation results were assigned different weights according to the imperviousness areas of the case study watershed.
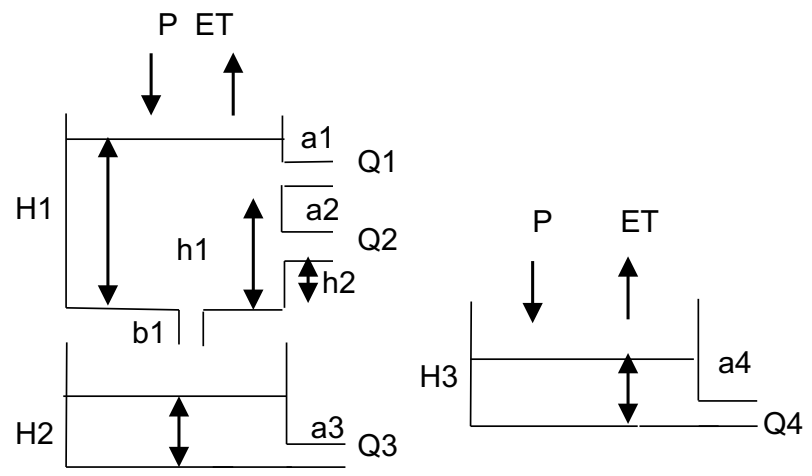

Permeable Tank model Impermeable Tank model

Figure 3 Schematic of the Tank model.

The interpretation of the parameters of the combination Tank model is as shown in Table 2. A spreadsheet was applied to conduct these equations to simulate the runoff.

Table 2 Tank model parameters used for calibration.

\begin{tabular}{ccl}
\hline Parameter & Unit & \\
\hline a1 & 1/d & Surface runoff coefficient of permeable Tank model \\
a2 & 1/d & Intermediate runoff coefficient of permeable Tank model \\
a3 & 1/d & Baseflow coefficient of permeable Tank model \\
a4 & 1/d & Surface runoff coefficient of impermeable Tank model \\
b1 & 1/d & Infiltration coefficient of permeable Tank model \\
h1 & $\mathrm{mm}$ & Height of surface outlet of permeable Tank model \\
h2 & $\mathrm{mm}$ & Height of intermediate outlet of permeable Tank model \\
H1 & $\mathrm{mm}$ & Initial storage of top tank of permeable Tank model \\
H2 & $\mathrm{mm}$ & Initial storage of bottom tank of permeable Tank model \\
H3 & $\mathrm{mm}$ & Initial storage of impermeable Tank model \\
Q1 & $\mathrm{mm} / \mathrm{d}$ & Surface runoff of permeable Tank model \\
Q2 & $\mathrm{mm} / \mathrm{d}$ & Intermediate runoff of permeable Tank model \\
Q3 & $\mathrm{mm} / \mathrm{d}$ & Baseflow of permeable Tank model \\
Q4 & $\mathrm{mm} / \mathrm{d}$ & Surface runoff of impermeable Tank model \\
Q & $\mathrm{mm} / \mathrm{d}$ & Total simulated discharge of the modified Tank model \\
Z1 & $\mathrm{mm} / \mathrm{d}$ & Infiltration of permeable Tank model \\
X1(t) & $\mathrm{mm}$ & Storage of top tank of permeable Tank model at t day \\
X2(t) & $\mathrm{mm}$ & Storage of bottom tank of permeable Tank model at t day \\
X3(t) & $\mathrm{mm}$ & Storage of impermeable Tank model at t day \\
$\mathrm{t}$ & $\mathrm{d}$ & Time lag \\
EP & $\mathrm{mm} / \mathrm{d}$ & Effective precipitation \\
\hline & & \\
\hline
\end{tabular}

The total simulation discharge of this type of Tank model consists of the sum of $50 \%$ of permeable tank model simulation discharge and $50 \%$ of permeable tank model simulation discharge.

$$
\begin{aligned}
& Q 1(t)=a 1 \times[X 1(t)-h 1] \\
& Q 2(t)=a 2 \times[X 1(t)-h 2] \\
& Q 3(t)=a 3 \times X 2(t) \\
& Q 4(t)=a 4 \times X 3(t) \\
& Z(t)=b 1 \times X 1(t) \\
& X 1(t)=X 1(t-1)+E P-Q 1(t)-Q 2(t)-Z(t) \\
& X 2(t)=X 2(t-1)+Z(t)-Q 3(t) \\
& X 3(t)=X 3(t-1)+E P-Q 4(t) \\
& Q(t)=50 \% \times[Q 1(t)+Q 2(t)+Q 3(t)]+50 \% \times Q 4(t)
\end{aligned}
$$

At the initial time $(t=0)$, the initial conditions of water level storage in both the permeable tank model and the impermeable tank model are given as $H 1, H 2$ and $H 3$.

\subsection{Calibration}

The parameters of the Tank model were calibrated using the Solver tool of Microsoft Excel by minimizing the root mean square error (RMSE) between observed and simulated daily flow records. Table 3 summarizes the results of the calibrated parameters.

Table 3 Calibrated parameters of the Tank model.

\begin{tabular}{cccccccccc}
\hline$a 1$ & $a 2$ & $a 3$ & $a 4$ & $b 1$ & $h 1$ & $h 2$ & $H 1$ & $H 2$ & $H 3$ \\
0.07 & 0.01 & 0.001 & 1.62 & 0.90 & 0.04 & 0.02 & 0 & 256 & 1 \\
\hline
\end{tabular}

Figure 4 shows the observed and simulated daily streamflows using the calibrated Tank model that shows a good match for a range of large and small storm events that occurred in the year 1991.

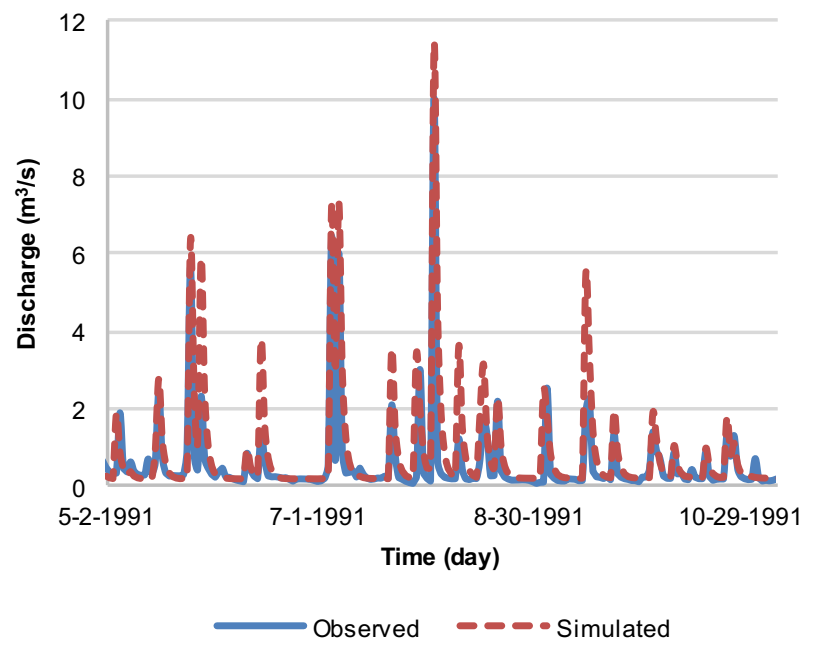

Figure 4 Comparison of simulated and observed hydrograph of the Tank model in 1991. 
However, comparison of the simulation results for 1992 (Figure 5) indicates that unmatched peak events occur in the winter and spring periods. This means the Tank model may not perform well in the winter period in Canada. To improve the performance of the Tank model in the future, the snowmelt algorithm of the Tank model mentioned in Sugawara (1985) should be taken into consideration.

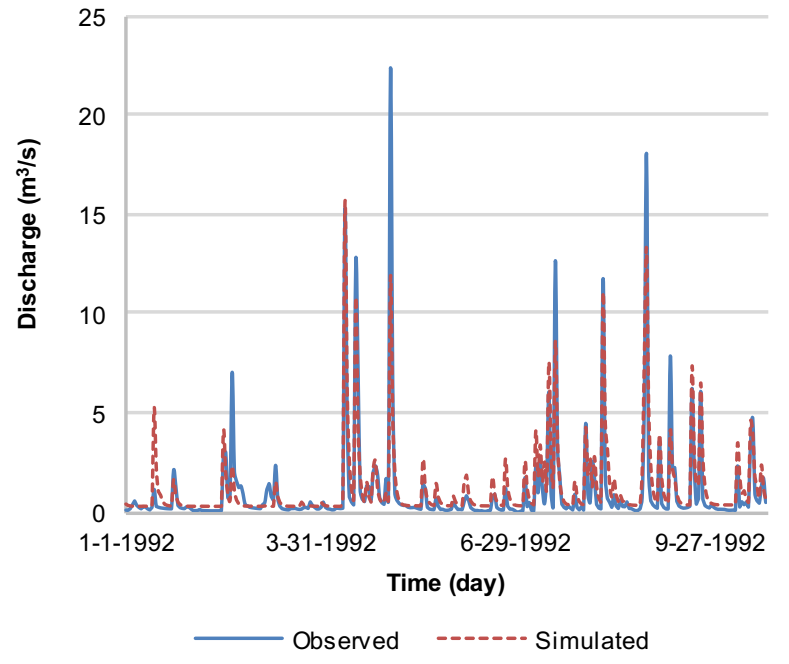

Figure 5 Comparison of simulated and observed hydrograph of the Tank model in 1992.

\subsection{Tank Model Application}

\section{Volume Analysis}

After the Tank model was calibrated, it was applied to analyse the relationship between the runoff and imperviousness of the urban area. Total runoff volume is one of the important hydrologic indicators, especially for design and retrofit of an urban drainage system with low impact development (LID) technology to increase permeable surface coverage. Table 4 indicates that total runoff volume will decrease from $347 \mathrm{~mm}$ to $303 \mathrm{~mm}$ if the percentage impervious cover is reduced from $50 \%$ to $40 \%$.

Table 4 Runoff volume for various imperviousness percentages.

\begin{tabular}{cc}
\hline Runoff Volume $(\mathrm{mm})$ & \% ImperviousCover \\
\hline 362 & $60 \%$ \\
347 & $50 \%$ \\
303 & $40 \%$ \\
\hline
\end{tabular}

Volume is expressed in mm normalized by the watershed drainage area $\left(70.6 \mathrm{~km}^{2}\right)$.

\section{Analysis of Peak Discharge}

Another important hydrologic indicator is peak discharge. The accurate prediction of peak discharge can effectively prevent property damage and protect the lives threatened. The values in Table 5 are the simulation results of the mean daily flood peaks varying with imperviousness during the period 1990-1992. The mean daily flood peaks will decrease significantly if thepercentage impervious cover is reduced from $50 \%$ today down to $40 \%$ through the implementation of permeable pavers and other LID systems to increase permeable surface coverage.

Table 5 Mean daily flood peaks variances with imperviousness from 1990 to 1992.

\begin{tabular}{|c|c|c|c|}
\hline \multirow{3}{*}{ Water Year } & \multicolumn{3}{|c|}{ Imperviousness } \\
\hline & $60 \%$ & $50 \%$ & $40 \%$ \\
\hline & $\left(\mathrm{m}^{3} / \mathrm{s}\right)$ & $\left(\mathrm{m}^{3} / \mathrm{s}\right)$ & $\left(\mathrm{m}^{3} / \mathrm{s}\right)$ \\
\hline 1990 & 9.50 & 8.74 & 6.59 \\
\hline 1991 & 12.31 & 11.38 & 8.58 \\
\hline 1992 & 16.86 & 15.59 & 11.75 \\
\hline Average & 12.89 & 11.90 & 8.97 \\
\hline$\%$ change & $+8 \%$ & Base Case & $-25 \%$ \\
\hline
\end{tabular}

\section{Conclusion}

A hydrologic model, known as the Tank model was used to investigate the effect of imperviousness on stormwater runoff volumes and peak flood flows. The Tank model includes algorithms for the simulation of stormwater runoff from impervious surfaces and both runoff and baseflow generated from pervious areas of the watershed. The model was successfully calibrated and tested, using historic records, for the case study watershed of Mimico Creek, Ontario for simulating daily flows.

Mimico Creek watershed is currently at 50\% imperviousness; however, the calibrated Tank model was used to investigate two very different future imperviousness scenarios. First, the implementation of extensive LID systems (e.g. porous pavements, green roofs and infiltration galleries) to reduce imperviousness down to $40 \%$, which would reduce mean annual streamflow volume by $12 \%$ and drop the peak flood flows by $25 \%$. Second, continue urbanization under a business-as-usual scenario to $60 \%$ imperviousness, which will increase runoff volumes by $4 \%$ and peak flood flows by $8 \%$.

In conclusion, the Tank model is a simple management tool for preliminary investigation of the potential effect of an increase or a decrease in the imperviousness of urbanizing watersheds on both runoff volumes and peak flood flows, in support of the implementation of low impact development technologies to protect the health of urban streams and their aquatic life.

\section{Acknowledgment}

The authors would like to acknowledge the support of the Natural Sciences and Engineering Research Council of Canada (NSERC) for their support of this research.

\section{References}

Basri, H. 2013. “Development of Rainfall-Runoff Model Using Tank Model: Problems and Challenges in Province of Aceh, 
Indonesia." Aceh International Journal of Science and Technology 2 (1).

Chow, V. T., D. R. Maidment and L. W. Mays 1988. Applied Hydrology. New York: McGraw-Hill.

Dietz, M. E. 2007. “Low Impact Development Practices: A Review of Current Research and Recommendations for Future Directions." Water, Air, \& Soil Pollution 186 (1-4): 351-63.

Dietz, M. E. and J. C. Clausen. 2008. "Stormwater Runoff and Export Changes with Development in a Traditional and Low Impact Subdivision." Journal of Environmental Management 87 (4): 560-6.

Elliott, A. H. and S. A. Trowsdale. 2007. "A Review of Models for Low Impact Urban Stormwater Drainage." Environmental Modelling \& Software 22 (3): 394-405.

Finney, K., B. Gharabaghi, E. A. McBean, R. P. Rudra and G. MacMillan. 2010. “Compost Biofilters for Highway Stormwater Runoff Treatment." Water Quality Research Journal of Canada 45 (4): 391-402.

Nirupama, N., C. Armenakis and M. Montpetit. 2014. "Is Flooding in Toronto a Concern?" Natural Hazards 72 (2): 1259-64.
Saini, S. and A. Singh. 2016."Modeling LID using SWMM5 and MIDS Credit Calculator: Credit Valley Conservation's Elm Drive Case Study." Journal of Water Management Modeling 25:C403. https://doi.org/10.14796/JWMM.C403.

Sugawara, M. 1985. “Tank model." Journal of Geography 94 (4): 209-21.

TRCA (Toronto and Region Conservation Authority). 2012. "Watershed Features: Etobicoke Creek and Mimico Creek." Toronto: TRCA.

https://rca.ca/conservation/watershed-management/ etobicoke-mimico-creek/watershed-features/.

UDFCD (Urban Drainage and Flood Control District). 2001. In Urban Storm Drainage Criteria Manual, vol. 3, Stormwater Quality, 143-56. Denver, CO: Urban Drainage and Flood Control District. http://udfcd.org/criteria-manual.

Yates, D. N. 1996. “WatBal: An Integrated Water Balance Model for Climate Impact Assessment of River Basin Runoff." International Journal of Water Resources Development 12 (2): 121-40. 